\title{
Copper and zinc metabolism in health and disease: speciation and interactions
}

\author{
BY IAN BREMNER AND JOHN H. BEATTIE \\ Rowett Research Institute, Greenburn Road, Bucksburn, Aberdeen AB2 9 SB
}

It has long been evident that the metabolism of trace elements cannot be considered in isolation. A wide range of nutritional and physiological factors can influence their uptake, transport and storage, with subsequent enhancement of susceptibility to deficiency or toxicity states. Interactions occur with other trace elements and these can be classified as competitive or non-competitive, direct or indirect. However, their physiological or toxicological significance is sometimes debatable, partly because they were demonstrated under extreme experimental conditions where massive doses of the antagonistic metal were administered, often by parenteral routes and to animals whose trace element status was already severely compromised. Our understanding of the mechanisms of the interactions is frequently limited and indeed in only a few cases has it been possible to describe these on a molecular basis.

It is almost traditional to cite the early work of Hill \& Matrone (1970) as the first serious attempt to describe trace element interactions on a rational basis. They postulated that elements with similar physical or chemical properties will act antagonistically to each other biologically. The implication was that such metals could compete for binding sites on transport proteins or on enzymes requiring metals as co-factors. Over subsequent years, much evidence was produced in support of this view but rarely was the specific site of interaction identified, other than at tissue level. In part this reflected somewhat embarrassing limitations in our knowledge of the proteins involved in the intracellular and extracellular transport and storage of trace metals.

\section{COPPER-ZINC INTERACTIONS}

The mutual antagonism between $\mathrm{Zn}$ and $\mathrm{Cu}$ has been regarded as a prime example of competitive biological interactions between metals with similar chemical and physical properties. This has been demonstrated in many investigations in a range of species. Thus, excessive $\mathrm{Zn}$ supply has been shown to inhibit intestinal absorption, hepatic accumulation and placental transfer of $\mathrm{Cu}$, as well as to induce clinical and biochemical signs of Cu deficiency (Bremner et al. 1976; Hall et al. 1979; L'Abbe \& Fischer, 1984; Yardick et al. 1989). The situation regarding the reverse interaction, namely the effects of $\mathrm{Cu}$ on $\mathrm{Zn}$ metabolism, has been less clear. Excessive $\mathrm{Cu}$ supply can affect hepatic $\mathrm{Zn}$ metabolism in some species but there is no consistent evidence that $\mathrm{Zn}$ absorption is seriously affected (Hall et al. 1979; Blalock et al. 1988). This casts some doubt on the mutuality of the interaction. Most of the early investigations were largely descriptive and they did little to elucidate the precise molecular basis or locus of the interaction.

$\mathrm{Cu}$ and $\mathrm{Zn}$ occupy a similar part of the periodic table, the $\mathrm{Zn}^{2+}$ and $\mathrm{Cu}^{+}$ions being isoelectronic and having similar ionic radii. Both metals readily form chelates with $\mathrm{O}-$, $\mathrm{S}$-, or $\mathrm{N}$-containing ligands but not always with the same stereochemical arrangement of bonds. However, unlike $\mathrm{Zn}$ which occurs in only one valency state, $\mathrm{Cu}$ can occur in two, as $\mathrm{Cu}^{+}$and $\mathrm{Cu}^{2+}$; indeed there have been suggestions that $\mathrm{Cu}^{3+}$ may also have a 
transient existence. $\mathrm{Cu}$, therefore, can play a major role in redox reactions and participates via the Haber-Weiss reaction in the generation of $O$ free-radicals which promote cellular instability. $\mathrm{Zn}$, on the other hand, has a stabilizing function and reputedly protects cell membranes against lipid peroxidation, and sulphydryl groups against oxidation (Willson, 1989). It plays an important role in maintaining the conformation of proteins, and ' $\mathrm{Zn}$ fingers' constitute ubiquitous structural elements in many transcription factors (Falchuk, 1993).

\section{COPPER AND ZINC ENZYMES}

There are differences also between $\mathrm{Cu}$ and $\mathrm{Zn}$ in the types of enzymes with which they are associated. Thus, $\mathrm{Cu}$ is frequently present in oxidases where its ability to exist in two oxidation states is integral to the activity of the enzyme. $\mathrm{Zn}$ is a component of dehydrogenases, proteases and esterases, its role often being to maintain the conformation of the enzyme, possibly as a $\beta$ sheet or in crosslinking between $S$ atoms (Williams, 1989). To the best of our knowledge, there is no evidence of substitution of $\mathrm{Cu}$ by $\mathrm{Zn}$, or vice versa, in any of these enzymes. One enzyme does contain both metals, superoxide dismutase ( $E C$ 1.15.1.1), but at clearly-defined sites, with $\mathrm{Zn}$ again having a structural role and $\mathrm{Cu}$ occurring at the active site and exercising a redox function. Williams (1989) has commented on the complementary role of $\mathrm{Zn}$ and $\mathrm{Cu}$ enzymes in regulating the composition of extracellular matrix and, thereby, cell growth and multiplication. Thus, $\mathrm{Zn}$ is a component of the collagenases and proteases that break down the extracellular matrix and, thus, permit cell movement, whereas $\mathrm{Cu}$ functions in the crosslinking and strengthening of the collagen which is an integral component of the matrix. The proper balance between $\mathrm{Zn}$ and $\mathrm{Cu}$ may be an essential ingredient of the alternating demands of stability and growth of the soft structures of an organism. Although changes in the activity of $\mathrm{Cu}$ enzymes may occur in animals or cells exposed to high levels of $\mathrm{Zn}$, there is no evidence that $\mathrm{Cu}$ is displaced from enzymes by $\mathrm{Zn}$, rather it seems that the availability of $\mathrm{Cu}$ has been reduced.

\section{TRANSPORT IN PLASMA}

If metalloenzymes do not constitute a site of interaction between $\mathrm{Cu}$ and $\mathrm{Zn}$, does the competition occur at the level of their transport systems? The enhanced uptake of $\mathrm{Zn}$, $\mathrm{Cd}, \mathrm{Pb}, \mathrm{Mn}$ and other metals in Fe-deficient animals is believed to reflect such competition and the ability of the metals to use transport systems for $\mathrm{Fe}$, possibly including transferrin (Hamilton et al. 1978). However, none of the plasma proteins which bind $\mathrm{Cu}$ or $\mathrm{Zn}$ appear to be involved in their mutual interaction. Caeruloplasmin and transcuprein bind only $\mathrm{Cu}$ whereas $\alpha 2$-macroglobulin binds only $\mathrm{Zn}$. Both metals bind to albumin, which is involved in their transport from the intestine to the liver but at different sites on the protein, the $\mathrm{Cu}$ being bound specifically at an $\mathrm{N}$-terminal histidine residue. Moreover, the molar concentration of albumin in plasma far exceeds that of $\mathrm{Cu}$ and $\mathrm{Zn}$, making it unlikely that competitive displacement of $\mathrm{Cu}$ by $\mathrm{Zn}$, or vice versa would ever occur. Small amounts of plasma $\mathrm{Cu}$ and $\mathrm{Zn}$ may be bound to metallothionein, and there is evidence of $\mathrm{Cu}$ displacing $\mathrm{Zn}$ from the protein in vivo (Bremner et al. 1987). This could result in increased renal uptake and urinary excretion of $\mathrm{Cu}$ as $\mathrm{Cu}$-metallothionein. 


\section{INBORN ERRORS OF COPPER METABOLISM}

Further indication that the metabolism of $\mathrm{Cu}$ and $\mathrm{Zn}$ is subject to quite different control is provided by the occurrence of metal-specific inborn errors of metabolism. Thus, Menkes' disease and Wilson's disease in humans and related conditions in animals such as Bedlington terriers, mottled mice, toxic milk mice and Long-Evans Cinnamon (LEC) rats are associated with severe disturbances in $\mathrm{Cu}$ metabolism, with only minor changes in tissue $\mathrm{Zn}$ concentration and never any clinical signs of $\mathrm{Zn}$ deficiency or toxicity. The basic defect in $\mathrm{Cu}$ metabolism in Wilson's disease and LEC rats is excessive hepatic accumulation of $\mathrm{Cu}$ and consequent liver damage. Plasma caeruloplasmin levels and biliary $\mathrm{Cu}$ excretion are reduced, implying a defect in the mechanisms whereby $\mathrm{Cu}$ is excreted from the liver (Gibbs \& Walshe, 1980; Sugawara et al. 1993). In contrast, Menkes' disease and the mottled mouse syndrome represent severe and often fatal forms of $\mathrm{Cu}$ deficiency, characterized by reductions in $\mathrm{Cu}$ absorption, liver $\mathrm{Cu}$ content and the activities of Cu-dependent enzymes (Danks, 1989). However, Cu concentrations in tissues such as the gut and kidneys increase, as they do also in cultured fibroblasts, indicating that there are defects in $\mathrm{Cu}$ transport systems in some tissues. $\mathrm{Zn}$ metabolism is essentially normal in Menkes' disease, Wilson's disease and related diseases.

Until recently, little "was known of the proteins involved in the control of $\mathrm{Cu}$ transport or of the genetic and metabolic basis of Wilson's disease or Menkes' disease. However, the successful cloning of the Menkes' gene (Mercer et al. 1993) and the gene for the murine homologue (Mercer et al. 1994) has transformed our views on the regulation of $\mathrm{Cu}$ transport. As yet, the Menkes' gene product has not been isolated but its structure has been deduced through sequence data of a cDNA. The gene product appears to consist of 1500 amino acids with six extended runs of hydrophobic amino acids typical of the transmembrane domains of a membrane-spanning protein. It contains five or six repeats of a metal-binding sequence motif at the $\mathrm{N}$-terminal part of the protein which is similar in alignment to bacterial $\mathrm{Cd}$ and $\mathrm{Hg}$ resistant systems in which P-type ATPases regulate heavy-metal efflux. Another single sequence at residues 1044-1050 contains an aspartic acid residue that serves as a phosphorylation site for an ATP-driven cation pump. This is believed to drive metal ions from the cytosol, in a similar manner to the $\mathrm{K}^{+}-\mathrm{Na}^{+}$ATPase (EC 3.6.1.37) which regulates intracellular $\mathrm{Na}$ concentrations. The Menkes' gene is expressed in tissues such as the gut, heart, brain, lung, muscle, pancreas and placenta but significantly not in the liver (Vulpe et al. 1993). Absence of the Cu transporter ATPase would be expected to result in impaired $\mathrm{Cu}$ efflux from cells, as indeed is found in Menkes' disease.

Similar studies on the structure of the Wilson's disease gene indicate that this also encodes a Cu-transporting ATPase (Bull et al. 1993). The gene shows high identity with the Menkes' gene, homology being $50 \%$ overall and $79 \%$ in the transduction, channel, phosphorylation and ATP-binding regions. Significantly the Wilson's disease gene is expressed mainly in the liver and kidney, which is appropriate for the clinical manifestations of the disease. This contrasts with the occurrence of the Menkes' gene in most tissues other than the liver and kidney (Vulpe et al. 1993). It is interesting that the Wilson's disease gene contains cysXXcys motifs in each of its metal-binding regions, together with one cysXcys motif in the transduction region. Similar motifs are characteristic of many transition-metal-binding proteins, are abundant in metallothionein and bind $\mathrm{Cu}$ in the reduced state. It is possible that this ability to reduce $\mathrm{Cu}$ is integral to the 
incorporation of $\mathrm{Cu}$ into apocaeruloplasmin and to the excretion of $\mathrm{Cu}$ in bile, both of which processes are impaired in Wilson's disease.

The discovery of these genes for putative Cu-transporting ATPases with contrasting tissue distribution is providing new insights into the study of $\mathrm{Cu}$ transport in health and disease. The occurrence of metal transporters with high degrees of homology in bacteria, animals and man indicates that they are of fundamental importance and also that further forms of the protein may await discovery. Although the gene products of the $\mathrm{Cu}$ transporting genes have yet to be isolated and characterized, there is no indication that they are implicated in the transport of $\mathrm{Zn}$ or constitute the site of interaction between these metals.

\section{CYSTEINE-RICH INTESTINAL PROTEIN (CRIP)}

Genetic disturbances in $\mathrm{Zn}$ metabolism occur in acrodermatitis enteropathica in humans and in A46 Friesian cattle, a defect in $\mathrm{Zn}$ absorption resulting in a severe $\mathrm{Zn}$ deficiency. The specific cause of the impaired $\mathrm{Zn}$ absorption is unknown but there have been suggestions that a CRIP plays a role in the transport of $\mathrm{Zn}$ across the gut mucosal epithelium in normal animals (Hempe \& Cousins, 1991, 1992). CRIP gene expression is most pronounced in the villus cells of the small intestine, reaching a peak of transcription during weaning in the rat (Birkenmeier \& Gordon, 1986). The deduced amino acid sequence for CRIP shows some similarity to that of certain ferredoxins (Birkenmeier \& Gordon, 1986) and contains a metal-binding LIM motif (C-X $2-C-X_{17-19}-H-X_{2}-C-X_{2}-C$ $\left.\mathrm{X}_{2}-\mathrm{C}-\mathrm{X}_{7-11}-(\mathrm{C})-\mathrm{X}_{8}-\mathrm{C}\right)$ which is also present as a two-copy tandem in 'Zn-finger' proteins (Wang et al. 1992; Levenson et al. 1993; Kosa et al. 1994).

In support of its proposed role as an intracellular $\mathrm{Zn}$-transport molecule, CRIP binds a large proportion of the $\mathrm{Zn}$ entering the intestinal mucosal cells at low lumen $\mathrm{Zn}$ concentrations and binding is saturable at higher levels. Nevertheless, expression of CRIP does not appear to be $\mathrm{Zn}$-dependent and there are no nucleic acid sequences upstream of the CRIP gene which have high homology to known metal regulatory elements (Levenson et al. 1994). Furthermore, the 1,25-hydroxycholecalciferolstimulated increase in $\mathrm{Zn}$ transport across a monolayer of Caco- 2 cells grown on permeable filter supports was accompanied by a reduction in CRIP expression (Fleet et al. 1993). Thus, the role of CRIP in $\mathrm{Zn}$ transport remains unresolved.

Studies of metal binding in vitro to proteins with LIM motifs, including CRIP, demonstrate the binding of $\mathrm{Cu}^{+}$with a maximal stoichiometry of three per motif compared with two for $\mathrm{Zn}^{2+}$ (Kosa et al. 1994). The tertiary folding of the $\mathrm{Zn}$ and $\mathrm{Cu}$ proteins are consequently distinct and this would probably have significant effects on their function. However, there is no evidence for binding of metals other than $\mathrm{Zn}$ to these proteins in vivo.

\section{STRESS-INDUCED DISTURBANCES IN COPPER AND ZINC METABOLISM}

Differences in $\mathrm{Cu}$ and $\mathrm{Zn}$ metabolism are also evident in response to physical and inflammatory stress and infection. These effects are mediated by a range of glucocorticoids and cytokines, including interleukins- 1 and -6 . A characteristic response is a sustained increase in plasma $\mathrm{Cu}$ concentrations, which is associated almost entirely with caeruloplasmin; this is widely recognized as an acute-phase protein. That the primary 
response is induction of caeruloplasmin synthesis in the liver and not $\mathrm{Cu}$ mobilization was confirmed by the demonstration that injection of $\mathrm{Cu}$-deficient rats with interleukin-1 resulted in production of caeruloplasmin-protein, although it was devoid of enzyme activity because of the absence of the necessary $\mathrm{Cu}$ co-factor (Barber \& Cousins, 1988). In contrast, the characteristic change in $\mathrm{Zn}$ metabolism after stress is a rapid and fairly transient decrease in plasma $\mathrm{Zn}$ concentrations which is associated with an increase in liver $\mathrm{Zn}$ content (Cousins, 1989). That these changes are directly related is supported by the results of compartmental analysis in rats injected with $\mathrm{Zn}^{65}$ following treatment with endotoxin or butyryl cyclic AMP (Dunn \& Cousins, 1989; Lowe et al. 1991). The clearance of $\mathrm{Zn}^{65}$ from the plasma could be described by a two-compartment model in which the initial pool $\left(\mathrm{Q}_{\mathrm{A}}\right)$ represented mainly plasma and the second pool $\left(\mathrm{Q}_{\mathrm{B}}\right)$ was located primarily within the liver. Although plasma $\mathrm{Zn}$ concentrations following endotoxin treatment fell, both $Q_{A}$ and $Q_{B}$ increased. However, the increase in $Q_{A}$ may have resulted from adverse effects of the endotoxin on cellular permeability. It appeared that $\mathrm{Q}_{\mathrm{B}}$ represented part of a metabolic pool within the liver and that this increased substantially in response to both the $\mathrm{Zn}$ loading and endotoxin treatment in a manner similar to that of the protein metallothionein. This is consistent with a plethora of reports that glucocorticoids, cytokines such as the interleukins and tumour necrosis factor, and other stress factors can induce metallothionein synthesis principally in the liver but also in other tissues (Bremner, 1987). Indeed, it appears that the decrease in plasma $\mathrm{Zn}$ levels after stress or infection is a direct consequence of the sequestration by the newly-induced thionein of $\mathrm{Zn}$ from the circulation. The physiological significance of these changes in $\mathrm{Cu}$ and $\mathrm{Zn}$ metabolism are still the subject of conjecture. There could be some advantage to the host in reducing circulating levels of $\mathrm{Zn}$ or possibly the increased production of caeruloplasmin and metallothionein is designed to cope with the oxidant challenge induced by the stress, since both these proteins can act as free radical scavengers.

\section{METALLOTHIONEIN}

Metallothionein is a low-molecular-weight cysteine-rich metal-binding protein which has a family of isoforms in some species and occurs in most tissues. Its synthesis is induced by metals such as $\mathrm{Zn}, \mathrm{Cu}$ and $\mathrm{Cd}$ and also by a range of pathophysiological factors which promote gene transcription directly in the case of metals, or indirectly through changes in cytokine or steroid levels (Palmiter, 1987). Transcription, which is elevated $1-2 \mathrm{~h}$ after metal-loading, involves activation of a nuclear-binding factor by metals and its binding to metal-responsive elements (MRE) situated upstream of the metallothionein gene. Recently, a transcription factor, MTF-1, which activates the mouse metallothionein promoter and contains six ' Zn fingers' has been cloned (Radtke et al. 1993). The process of factor activation by metals is as yet unknown but Palmiter (1994) has proposed a mechanism involving an inhibitor protein which normally interacts with the ' $\mathrm{Zn}$ fingers' of MTF-1 thereby preventing its binding to MRE. In the presence of $\mathrm{Zn}$ it is proposed that the inhibitor dissociates from MTF-1 and promotion of transcription can proceed. Transcription studies of BHK cells transfected with a metallothionein MRE$\beta$-galactosidase (EC 3.2.1.23) gene construct and also an MTF-1 construct with a viral promoter sequence showed that the expression of $\beta$-galactosidase by $\mathrm{Cu}$ was highly dependent on the presence of $\mathrm{Zn}$ in the incubation medium, whereas $\mathrm{Cd}$ induction did not appear to be $\mathrm{Zn}$-dependent (Palmiter, 1994). The relative induction of metallo- 
thionein gene transcription by $\mathrm{Cu}$ and $\mathrm{Zn}$ is species and tissue or cell dependent and is influenced by the way in which the metal is administered. For example, metallothionein mRNA levels were significantly elevated in the kidney but not the small intestine of rats fed on a high-Cu diet $(36 \mathrm{mg} \mathrm{Cu} / \mathrm{kg}$ ) whereas increased levels of message were detected in both tissues following high dietary $\mathrm{Zn}$ treatment $(180 \mathrm{mg} \mathrm{Zn} / \mathrm{kg}$ ) (Blalock et al. 1988). The different isoforms of metallothionein code from distinct genes which are linked on the same chromosome and are usually coordinately expressed (Lehman-McKeeman et al. 1991). However, differential expression of isoform genes has been noted in certain species and in response to different inducers. For example, sheep have at least four functioning metallothionein genes (Peterson et al. 1988) and when comparing the isoform induction by $\mathrm{Cu}$ and $\mathrm{Zn}$ in sheep fibroblast cultures, $\mathrm{Cu}$ appears to be a less effective inducer of MT-1c transcription (Peterson \& Mercer, 1988). Furthermore, there is growing evidence for discrepancies in the translational control of isoform expression (Lehman-McKeeman et al. 1988; Paynter et al. 1990) and possible differences in the functional roles of metallothionein isoforms has not been adequately addressed.

The cysteine residues in metallothionein are highly conserved between isoforms, their distinctive characteristics arising from substitution of $2-25 \%$ of the remaining amino acids. The metal-saturated form of metallothionein contains seven divalent metals such as $\mathrm{Zn}$ and $\mathrm{Cd}$ but $\mathrm{Cu}$, which is always present in the $\mathrm{Cu}^{+}$form, has a binding ratio of 12 in vivo. All the cysteine residues are involved in metal binding in two separate domains or metal-S clusters. Cysteine:metal values are 3:1 for $\mathrm{Zn}$ metallothionein but only 2:1 for $\mathrm{Cu}-$ metallothionein and yet the arrangement of $\mathrm{S}$ atoms around each metal is tetrahedral and trigonal respectively. This implies that there are bridging $S$ atoms between some of the metal atoms. In addition to these differences in the stereochemical arrangement of ligands around the $\mathrm{Cu}$ and $\mathrm{Zn}$ atoms, the metals differ in their preferential binding for the two domains within the protein. On titration of the apoprotein with $\mathrm{Zn}$ or $\mathrm{Cd}$, the C-terminal $\alpha$ domain fills preferentially with four metal atoms followed by three in the $\mathrm{N}$-terminal $\beta$ domain (Nielson \& Winge, 1983; Stillman \& Zelazowski, 1988). Cu on the other hand shows preferential binding to the $\beta$ domain (Nielson \& Winge, 1984). The avidity with which these metals bind to metallothionein decreases in the order $\mathrm{Cu}>\mathrm{Cd}>\mathrm{Zn}$ and, in contrast to apoprotein, the binding of $\mathrm{Cd}$ to $\mathrm{Zn}_{7}-$ metallothionein is initially random, although redistribution of metals to the more thermodynamically stable and domain-specific position can be activated by raising the temperature to $65^{\circ}$ (Stillman et al. 1987). Therefore, in the presence of $\mathrm{Cd}$ or $\mathrm{Cu}, \mathrm{Zn}$ could be regarded as having a passive binding role to complete the full complement of metals and, thus, maintain the structural integrity of the protein.

Concentrations of metallothionein in tissues depend on their $\mathrm{Zn}$ and to a lesser extent $\mathrm{Cu}$ concentrations, which is consistent with the inducibility of protein synthesis by these metals. Almost invariably, metallothionein binds most of the hepatic $\mathrm{Zn}$ above a threshold concentration which is similar to that found in $\mathrm{Zn}$-deficient animals. However, the binding of hepatic $\mathrm{Cu}$ to metallothionein is more variable and depends on factors such as species, route of $\mathrm{Cu}$ administration, and $\mathrm{Zn}$ status. For example, compared with many species in which hepatic metallothionein levels are largely unaffected by moderately elevated levels of dietary $\mathrm{Cu}$, dogs and pigs show increased levels of this protein. A factor common to these two species is the absence of a specific Cu-binding site on serum albumin (SA) and there is evidence that when rat primary hepatocyte cultures are incubated with $\mathrm{Cu}$ bound to various $\mathrm{SA}$, cellular metallothionein but not cellular $\mathrm{Cu}$ 
is higher in the presence of canine SA (Beattie et al. 1993). Although metallothionein often contains $\mathrm{Zn}$ as the only bound metal, it is only in extreme $\mathrm{Cu}$-loading situations that $\mathrm{Cu}$ is present without $\mathrm{Zn}$ as a secondary bound metal. $\mathrm{Cu}-$ metallothionein is generally absent from the livers of $\mathrm{Zn}$-deficient animals, even at very high liver $\mathrm{Cu}$ concentrations, despite the fact that $\mathrm{Cu}$ can induce synthesis of metallothionein in these animals. This may reflect in part the reduced biological half-life of metallothionein in Zn-deficient animals. Although metallothionein is generally regarded as a cytosolic protein, it has been shown by immunocytochemical techniques to occur within the nucleus. The distribution of the protein between these two compartments is variable, with concentrated nuclear metallothionein appearing during cell proliferation, for example at S-phase during epidermal growth factor-stimulated hepatocyte proliferation (Tsujikawa et al. 1991), during liver regeneration after hepatectomy (Tohyama et al. 1993) and in liver during fetal development (Nartey et al. 1987). Aggregated forms of the protein also accumulate in particulate fractions of the liver, including the lysosomes, after extreme Cu loading (Bremner, 1987).

The rapid changes in metallothionein concentrations in response to metal administration imply that it has a regulatory function, the nature of which is not yet entirely clear. One possibility is that the protein acts as a $\mathrm{Zn}$ buffer, designed to prevent increased intracellular concentrations of free $\mathrm{Zn}$ ions (Bremner, 1993). This provides a mechanism whereby $\mathrm{Zn}$ can be transiently stored before it is incorporated into metalloenzymes, used to support growth and development, or excreted. There is also good evidence that the protein is involved in the cellular detoxification of $\mathrm{Cu}$. This is particularly evident in cell lines in which the level of metallothionein expression has been enhanced, as these cells are much more tolerant of $\mathrm{Cu}$ than are the wild-type cells (Freedman, 1989). The protective effect of $\mathrm{Zn}$ against $\mathrm{Cu}$-induced liver damage, also, has been ascribed to an increased binding of $\mathrm{Cu}$ to metallothionein. Similarly, species which are able to accumulate large amounts of hepatic $\mathrm{Cu}$ as metallothionein are generally tolerant of $\mathrm{Cu}$-induced liver dysfunction. However, fulminant hepatitis occurs at lower liver $\mathrm{Cu}$ concentrations in LEC rats than in normal strains, despite the fact that metallothionein concentrations are much greater in the former animals (Sugawara et al. 1992).

There have been many attempts to ascribe tissue-specific functions to metallothionein, despite the fact that its ubiquity implies a general role in control of cellular metabolism. For example, it was suggested many years ago that metallothionein is involved in the control of intestinal $\mathrm{Zn}$ absorption (Richards \& Cousins, 1976). This was based on the observation of an inverse relationship between the efficiency of absorption and mucosal metallothionein concentrations, which suggested that binding of dietary $\mathrm{Zn}$ to metallothionein on the mucosa provided a mechanism for restricting basolateral transfer of $\mathrm{Zn}$ to the circulation. In essence, metallothionein could act as a mucosal block to $\mathrm{Zn}$ absorption. Attractive though this hypothesis is, the mucosal metallothionein content does not change significantly over a physiological range of dietary $\mathrm{Zn}$ intakes, where the efficiency of absorption varies as part of the homeostatic control mechanism (Hall et al. 1979; Blalock et al. 1988). Moreover, the amount of $\mathrm{Zn}$ trapped on mucosal metallothionein represents only a small proportion of the dietary $\mathrm{Zn}$ intake. It seems, therefore, that the increase in mucosal metallothionein concentrations that occurs at high dietary $\mathrm{Zn}$ intakes represent a partial failure rather than an essential component of homeostatic control mechanism, in so far as it may only occur after mucosal $\mathrm{Zn}$ concentrations have 
increased. Indeed, the affinity of metallothionein for $\mathrm{Zn}$ is of such magnitude that at high dietary $\mathrm{Zn}$ levels, a large proportion of the metal bound to the putative intracellular transporter CRIP is scavenged by metallothionein. The evidence that metallothionein plays a role in the control of $\mathrm{Cu}$ absorption is even less convincing. No changes in mucosal metallothionein concentrations occur in response to substantial changes in $\mathrm{Cu}$ supply (Hall et al. 1979; Blalock et al. 1988). Although the decreased efficiency of $\mathrm{Cu}$ absorption in brindled mice is associated with excessive accumulation of $\mathrm{Cu}$ bound to intestinal metallothionein, this is almost certainly a consequence of the defect in the efflux of $\mathrm{Cu}$ from the mucosal cells.

Despite this, intestinal metallothionein may be implicated in the antagonistic effect of $\mathrm{Zn}$ on $\mathrm{Cu}$ metabolism. Thus, high dietary $\mathrm{Zn}$ intakes inhibited the absorption of oral $\mathrm{Cu}^{64}$ in rats, this being associated with an increase in the binding of the $\mathrm{Cu}^{64}$ in the mucosa in the form of metallothionein (Hall et al. 1979; Oestreicher \& Cousins, 1985). A dose-response trial revealed that the absorption of $\mathrm{Cu}$ was only inhibited at $\mathrm{Zn}$ intakes that caused substantial increases in mucosal metallothionein concentration. Moreover, the amount of $\mathrm{Cu}^{64}$ trapped in the mucosa as metallothionein was almost equivalent to the $\mathrm{Zn}$-induced reduction in the carcass accumulation of the isotope. It seems, therefore, that high $\mathrm{Zn}$ intakes result in increased production in the gut of metallothionein which then binds $\mathrm{Cu}$ in preference to $\mathrm{Zn}$, thereby blocking transfer of the $\mathrm{Cu}$ across the basolateral membrane and inhibiting absorption. This hypothesis assumes that $\mathrm{Cu}$ on metallothionein is not available for reabsorption after desquamation of the intestinal cells. This does not necessarily represent the only mechanism whereby $\mathrm{Zn}$ affects $\mathrm{Cu}$ accumulation, as it seems that low levels of $\mathrm{Zn}$ can affect $\mathrm{Cu}$ metabolism without inducing mucosal metallothionein production (Oestreicher \& Cousins, 1985). Moreover, there are direct effects of $\mathrm{Zn}$ on hepatic $\mathrm{Cu}$ distribution that appear to be modulated by metallothionein (Bremner, 1993).

\section{CLINICAL IMPLICATIONS}

The interaction between $\mathrm{Cu}$ and $\mathrm{Zn}$ is of importance in both animal production and clinical medicine. Thus, $\mathrm{Zn}$ supplements have been found to induce hypocupraemia and associated neutropenia and microcytosis when used to treat patients with sickle cell anaemia; these conditions were corrected by $\mathrm{Cu}$ administration (Prasad et al. 1978). Moreover, they have induced negative Cu balance (Sandstead et al. 1982) and reduced erythrocyte superoxide dismutase activities (Fischer et al. 1984) in normal subjects. This suggests that care should be taken in the use of $\mathrm{Zn}$ supplements, particularly where $\mathrm{Cu}$ status is suboptimal.

However, Zn supplementation offers a means of treating conditions associated with excessive $\mathrm{Cu}$ accumulation, whether caused by dietary intake or genetic disturbances in $\mathrm{Cu}$ metabolism. Thus, $\mathrm{Zn}$ supplements reduce the incidence of $\mathrm{Cu}$ toxicosis in sheep (Bremner et al. 1976) and are now used to treat Wilson's disease in humans (Hoogenraad et al. 1978; Brewer et al. 1983). Brewer et al. (1993) have established the optimumdosage regimen to reduce $\mathrm{Cu}$ absorption and to restore $\mathrm{Cu}$ balance. It appears that a daily dose of $75 \mathrm{mg} \mathrm{Zn}$ as zinc acetate, divided into at least two doses and given between meals, is most effective (Brewer et al. 1993). This treatment can be used as maintenance therapy and for treatment of presymptomatic patients. That the $\mathrm{Zn}$-induced decrease in $\mathrm{Cu}$ absorption is due to increased production of intestinal metallothionein is suggested by 
the results of direct measurement of the protein in intestinal biopsies (YuzbasiyanGurkan et al. 1992). Intestinal metallothionein concentrations were linearly correlated with urinary $\mathrm{Zn}$ levels which reflected $\mathrm{Zn}$ status. However, it is possible that $\mathrm{Zn}$ also affects the hepatic distribution of $\mathrm{Cu}$ and increases the proportion bound to metallothionein, with concomitant reduction in its hepatotoxicity.

\section{REFERENCES}

Barber, E. F. \& Cousins, R. J. (1988). Interleukin-1-stimulated induction of ceruloplasmin synthesis in normal and copper-deficient rats. Journal of Nutrition 118, 375-381.

Beattie, J. H., Black, D. J. \& Bremner, 1. (1993). In Trace Elements in Man and Animals - TEMA 8, pp. 159-163 [M. Anke, D. Meissner and C. F. Mills, editors]. Gersdorf: Verlag Media Touristik.

Birkenmeier, E. H. \& Gordon, J. I. (1986). Developmental regulation of a gene that encodes a cysteine-rich intestinal protein and maps near the murine immunoglobulin heavy chain locus. Proceedings of the National Academy of Sciences, USA 83, 2516-2520.

Blalock, T. L., Dunn, M. A. \& Cousins, R. J. (1988). Metallothionein gene expression in rats: tissue-specific regulation by dietary copper and zinc. Journal of Nutrition 118, 222-228.

Bremner, I. (1987). Nutritional and physiological significance of metallothionein. In Metallothionein II: Proceedings of the 2nd International Symposium on Metallothionein and Other Low Molecular Weight Metal-Binding Proteins, pp. 81-107 [J. H. R. Kägi and Y. Kojima, editors]. Basel: Birkhäuser Verlag.

Bremner, J. (1993). Involvement of metallothionein in the regulation of mineral metabolism. In Metallothionein 1II. Biological Roles and Medical Implications, pp. 111-124 [K. T. Suzuki, N. Imura and M. Kimura, editors]. Basel: Birkhaüser Verlag AG.

Bremner, I., Mehra, R. K. \& Sato, M. (1987). Metallothionein in blood, bile and urine. In Metallothionein II: Proceedings of the 2nd International Symposium on Metallothionein and Other Low Molecular Weight Metal-Binding Proteins, pp. 507-517 [J. H. R. Kägi and Y. Kojima, editors]. Basel: Birkhäuser Verlag.

Bremner, I., Young, B. W. \& Mills, C. F. (1976). Protective effect of zinc supplementation against copper toxicosis in sheep. British Journal of Nutrition 36, 551-561.

Brewer, G. J., Hill, G. M., Prasad, A. S., Cossack, Z. T. \& Rabbani, P. (1983). Oral zinc therapy for Wilson's disease. Annals of Internal Medicine 99, 314-320.

Brewer, G. J., Yuzbasiyan-Gurkan, V., Johnson, V., Dick, R. D. \& Wang, Y. (1993). Treatment of Wilson's disease with zinc: XII. Dose regimen requirements. American Journal of Medical Science 305, 199-202.

Bull, P. C., Thomas, G. R., Rommens, J. M., Forbes, J. R. \& Cox, D. W. (1993). The Wilson disease gene is a putative copper transporting P-type ATPase similar to the Menkes gene. Nature Genetics 5, 327-337.

Cousins, R. J. (1989). Systemic transport of zinc. In Zinc in Human Biology, pp. 79-93 [C. F. Mills, editor]. London: Springer-Verlag.

Danks, D. M. (1989). Hereditary disorders of copper metabolism in Wilson's disease and Menkes' disease. In The Metabolic Basis of Inherited Diseases, pp. 1411-1431 [C. R. Scriver, A. Beaudet, W. J. Sly and D. Velle, editors]. New York: McGraw-Hill.

Dunn, M. A. \& Cousins, R. J. (1989). Kinetics of zinc metabolism in the rat: effect of dibutyryl cAMP. American Journal of Physiology 256, E420-E430.

Falchuk, K. H. (1993). Zinc in developmental biology: the role of metal-dependent transcription regulation. In Essential and Toxic Elements in Human Health and Disease: An Update, pp. 91-111 [A. S. Prasad, editor]. New York: Wiley-Liss.

Fischer, P. W. F., Giroux, A. \& L'Abbe, M. R. (1984). Effect of zinc supplements on copper status in adult men. American Journal of Clinical Nutrition 40, 743-746.

Fleet, J. C., Turnbull, A. J., Bourcier, M. \& Wood, R. J. (1993). Vitamin D-sensitive and quinacrine-sensitive zinc transport in human intestinal cell line Caco-2. American Journal of Physiology 264, G1037-G1045.

Freedman, J. H., Ciriolo, M. R. \& Peisach, J. (1989). The role of glutathione in copper metabolism and toxicity. Journal of Biological Chemistry 264, 5598-5605.

Gibbs, K. \& Walshe, J. M. (1980). Biliary excretion of copper in Wilson's disease. Lancet ii, 538-539.

Hall, A. C., Young, B. W. \& Bremner, I. (1979), Intestinal metallothionein and the mutual antagonism between copper and zinc in the rat. Journal of Inorganic Biochemistry 11, 57-66.

Hamilton, D. L., Bellamy, J. E. C., Valberg, J. D. \& Valberg, L. S. (1978). Zinc, cadmium and iron interaction during intestinal absorption in iron-deficient mice. Canadian Journal of Physiology and Pharmacology 56, 384-388. 
Hempe, J. M. \& Cousins, R. J. (1991). Cysteine-rich intestinal protein binds zinc during transmucosal zinc transport. Proceedings of the National Academy of Science, USA 88, 9671-9674.

Hempe, J. M. \& Cousins, R. J. (1992). Cysteine-rich intestinal protein and intestinal metallothionein: an inverse relationship as a conceptual model for zinc absorption in rats. Journal of Nutrition 122, 89-95.

Hill, C. H. \& Matrone, G. (1970). Chemical parameters in the study of in vivo and in vitro interactions of transition elements. Federation Proceedings 29, 1474-1481.

Hoogenraad, T. U., Van den Hamer, C. J. A., Koevoet, R. \& de Ruylir Korver, E. G. W. M. (1978). Oral zinc in Wilson's disease. Lancet $\mathbf{I}, 1262$.

Kosa, J. L., Michelsen, J. W., Louis, H. A., Olsen, J. I., Davis, D. R., Beckerle, M. C. \& Winge, D. R. (1994). Common metal ion coordination in LIM domain proteins. Biochemistry 33, 468-477.

L'Abbe, M. R. \& Fischer, P. W. F. (1984). The effects of dietary zinc on the activity of copper-requiring metalloenzymes. Journal of Nutrition 114, 823-828.

Lehman-McKeeman, L. D., Andrews, G. K. \& Klaassen, C. D. (1988). Mechanisms of regulation of rat hepatic metallothionein-I and metallothionein-II levels following administration of zinc. Toxicology and Applied Pharmacology 92, 1-9.

Lehman-McKeeman, L. D., Kershaw, W. C. \& Klaassen, C. D. (1991). Species differences in metallothionein regulation: a comparison of the induction of isometallothioneins in rats and mice. In Metallothionein in Biology and Medicine, pp. 121-131 [C. D. Klaassen and K. T. Suzuki, editors]. Boca Raton: CRC Press Inc.

Levenson, C. W., Shay, N. F., Hempe, J. M. \& Cousins, R. J. (1994). Expression of cysteine-rich intestinal protein in rat intestine and transfected cells is not zinc dependent. Journal of Nutrition 124, 13-17.

Levenson, C. W., Shay, N. F., Lee-Ambrose, L. M. \& Cousins, R. J. (1993). Regulation of cysteine-rich intestinal protein by dexamethasone in the neonatal rat. Proceedings of the National Academy of Science, USA 90, 712-715.

Lowe, N. M., Bremner, I. \& Jackson, M. J. (1991). Plasma ${ }^{65} \mathrm{Zn}$ kinetics in the rat. British Journal of Nutrition $65,445-455$.

Mercer, J. F. B., Grimes, A., Ambrosini, L., Lockhart, P., Paynter, J. A., Dierick, H. \& Glover, T. W. (1994). Mutations in the murine homologue of the Menkes gene in dappled and blotchy mice. Nature Genetics 6, 374-378.

Mercer, J. F. B., Livingston, J., Hall, B., Paynter, J. A., Begy, C., Chandrasekharappa, S., Lockhart, P., Grimes, A., Bhave, M., Siemieniak, D. \& Glover, T. W. (1993). Isolation of a partial candidate gene for Menkes disease by positional cloning. Nature Genetics 3, 20-25.

Nartey, N. O., Banerjee, D. \& Cherian, M. G. (1987). Immunohistochemical localization of metallothionein in cell nucleus and cytoplasm of fetal human liver and kidney and its changes during development. Pathology 19, 233-238.

Nielson, K. B. \& Winge, D. R. (1983). Order of metal binding in metallothionein. Journal of Biological Chemistry 258, 13063-13069.

Nielson, K. B. \& Winge, D. R. (1984). Preferential binding of copper to the $\beta$ domain of metallothionein. Journal of Biological Chemistry 259, 4941-4946.

Oestreicher, P. \& Cousins, R. J. (1985). Copper and zinc absorption in the rat: mechanism of mutual antagonism. Journal of Nutrition 115, 159-166.

Palmiter, R. D. (1987). Molecular biology and metallothionein gene expression. In Metallothionein II: Proceedings of the 2nd International Symposium on Metallothionein and Other Low Molecular Weight Metal-Binding Proteins, pp. 63-80 [J. H. R. Kägi and Y. Kojima, editors]. Basel: Birkhäuser Verlag.

Palmiter, R. D. (1994). Regulation of metallothionein genes by heavy metals appears to be mediated by a zinc-sensitive inhibitor that interacts with a constitutively active transcription factor, MTF-1. Proceedings of the National Academy of Science, USA 91, 1219-1223.

Paynter, J. A., Camakaris, J. \& Mercer, J. F. B. (1990). Analysis of hepatic copper, zinc, metallothionein and metallothionein-Ia mRNA in developing sheep. European Journal of Biochemistry 190, 149-154.

Peterson, M. G., Hannan, F. \& Mercer, J. F. B. (1988). The sheep metallothionein gene family. Structure, sequence and evolutionary relationship of five linked genes. European Journal of Biochemistry 174, $417-424$.

Peterson, M. G. \& Mercer, J. F. B. (1988). Differential expression of four linked sheep metallothionein genes. European Journal of Biochemistry 174, 425-429.

Prasad, A. S., Brewer, G. J., Schoomaker, E. B. \& Rabbani, P. (1978). Hypocupremia induced by zinc therapy in adults. Journal of the American Medical Association 240, 2166-2168. 
Radtke, F., Heuchel, R., Georgiev, O., Hergersberg, M., Gariglio, M., Dembic, Z. \& Schaffner, W. (1993). Cloned transcription factor MTF-1 activates the mouse metallothionein I promotor. The EMBO Journal 12, 1355-1362.

Richards, M. P. \& Cousins, R. J. (1976). Metallothionein and its relationship to the metabolism of dietary zinc in the rat. Journal of Nutrition 106, 1591-1599.

Sandstead, H. H. (1982). Copper bioavailability and requirements. American Journal of Clinical Nutrition 35, 809-814.

Stillman, M. J., Cai, W. \& Zelazowski, A. J. (1987). Cadmium binding to metallothioneins. Domain specificity in reactions of $\alpha$ and $\beta$ fragments, apometallothionein, and zinc metallothionein with $\mathrm{Cd}^{2+}$. Joumal of Biological Chemistry 262, $4538-4548$.

Stillman, M. J. \& Zelazowski, A. J. (1988). Domain specificity in metal binding to metallothionein. A circular dichroism and magnetic circular dichroism study of cadmium and zinc binding at temperature extremes. Journal of Biological Chemistry 263, 6128-6133.

Sugawara, N., Li, D., Sugawara, C. \& Miyake, H. (1993). Decrease in biliary excretion of copper in Long-Evans Cinnamon (LEC) rats causing spontaneous hepatitis due to a gross accumulation of hepatic copper. Research Communications in Chemical Pathology and Pharmacology 81, 45-52.

Sugawara, N., Sugawara, C., Sato, M., Takahashi, H. \& Mori, M. (1992). Excessive accumulation of hepatic copper in LEC rats aged 80 days without hapatitis and 130 days with hepatitis. Pharmacology and Toxicology 71, 321-324.

Tohyama, C., Suzuki, J. S., Hemelraad, J., Nishimura, N. \& Nishimura, H. (1993). Induction of metallothionein and its localization in the nucleus of rat hepatocytes after partial hepatectomy. Hepatology 18 , 1193-1201.

Tsujikawa, K., Imai, T., Kakutani, M., Kayamori, Y., Mimura, T., Otaki, N., Kimura, M., Fukuyama, R. \& Shimizu, N. (1991). Localization of metallothionein in nuclei of growing primary cultured adult rat hepatocytes. FEBS Letters 283, 239-242.

Vulpe, C., Levinson, B., Whitney, S., Packman, S. \& Gitschier, J. (1993). Isolation of a candidate gene for Menkes disease and evidence that it encodes a copper-transporting ATPase. Nature Genetics 3, 7-13.

Wang, X., Lee, G., Liebhaber, S. A. \& Cooke, N. E. (1992). Human cysteine-rich protein. A member of the LIM/double-finger family displaying coordinate serum induction with c-myc. Joumal of Biological Chemistry 267, 9176-9184.

Weismann, K., Hoe, S., Knudsen, L. \& Sorensen, S. S. (1979). ${ }^{65} \mathrm{Zn}$ absorption in patients suffering from acrodermatitis enteropathica and in normal adults assessed by whole-body counting technique. British Journal of Dermatology 101, 573-579.

Williams, R. J. P. (1989). An introduction to the biochemistry of zinc. In Zinc in Human Biology, pp. 15-31 [C. F. Mills, editor]. London: Springer-Verlag.

Willson, R. L. (1989). Zinc and iron in free radical pathology and cellular control. In Zinc in Human Biology, pp. 147-172 [C. F. Mills, editor]. London: Springer-Verlag.

Yardick, M. K., Kenney, M. A. \& Winterfield, E. A. (1989). Iron, copper and zinc status: response to supplementation with zinc or zinc and iron in adult females. American Journal of Clinical Nutrition 49, 145-150.

Yuzbasiyan-Gurkan, V., Grider, A., Nostrant, T., Cousins, R. J. \& Brewer, G. J. (1992). Treatment of Wilson's disease with zinc: $\mathrm{X}$. Intestinal metallothionein induction. Journal of Laboratory Clinical Medicine $120,380-386$. 